\title{
Evaluation of Morphophysiological and Biochemical Features in Young Plants of Khaya senegalensis Under Increasing Salinity
}

\author{
Willian Viana Campos \\ Faculty of Agricultural Engineering, State University of Campinas, Campinas, São Paulo, \\ Brazil \\ E-mail: willianvianac@hotmail.com
}

Paulo Araquém Ramos Cairo (Corresponding Author)

Departament of Crop and Animal Science, State University of Sowthwest Bahia, Vitória da Conquista, Bahia, Brazil

E-mail: pcairo@uol.com.br

Raul Antônio Araújo do Bonfim

Departament of Crop and Animal Science, State University of Sowthwest Bahia, Vitória da Conquista, Bahia, Brazil

E-mail: raularaujoraul@gmail.com

Mateus Pires Barbosa

Departament of Crop and Animal Science, State University of Sowthwest Bahia, Vitória da Conquista, Bahia, Brazil

E-mail: mateus_pbarbosa@hotmail.com

Leandro Dias da Silva

Departament of Crop and Animal Science, State University of Sowthwest Bahia, Vitória da Conquista, Bahia, Brazil

E-mail: leodias5@yahoo.com.br 
Mikaela Oliveira Souza

Departament of Crop and Animal Science, State University of Sowthwest Bahia, Vitória da Conquista, Bahia, Brazil

E-mail: mikaelasouza.o@gmail.com

\author{
Milton Carriço Sá \\ Departament of Crop and Animal Science, State University of Sowthwest Bahia, Vitória da \\ Conquista, Bahia, Brazil \\ E-mail: milton.carrico@hotmail.com
}

Received: Mar. 6, 2020

Accepted: Apr. 2, 2020

Published: Apr. 13, 2020

doi:10.5296/jas.v8i3.16617

URL: https://doi.org/10.5296/jas.v8i3.16617

\begin{abstract}
A greenhouse study was carried out to evaluate the effects of increasing sodium chloride $(\mathrm{NaCl})$ concentrations in a nutrient solution on growth-related morphophysiological and biochemical features during development of young plants of African mahogany (Khaya senegalensis). The $\mathrm{NaCl}$ concentrations were $0 \mathrm{mM}\left(1.0 \mathrm{dS} \mathrm{m}{ }^{-1}\right), 20 \mathrm{mM}\left(3.38 \mathrm{dS} \mathrm{m}^{-1}\right), 145$ $\mathrm{mM}\left(15.14 \mathrm{dS} \mathrm{m}^{-1}\right), 270 \mathrm{mM}\left(29.90 \mathrm{dS} \mathrm{m}^{-1}\right), 395 \mathrm{mM}$ (42.61 dS m $\left.\mathrm{m}^{-1}\right)$ and $520 \mathrm{mM}$ (53.60 dS $\mathrm{m}^{-1}$ ). Morphological features were negatively affected by increasing $\mathrm{NaCl}$ concentrations, except for plant height, which had no significant effect. Relative water content was not affected, whereas water potential decreased, suggesting osmotic adjustment. Whole plant dry mass was reduced, especially on roots, whose dry mass reduced up to $66 \%$ lower than in control. Regarding biochemical features, chlorophyll, chlorophyll content was reduced by salinity stress from $15.14 \mathrm{dS} \mathrm{m}^{-1}$, whereas reducing sugars, starch and proline contents were increased. We conclude that in the early development Khaya senegalensis is tolerant to salinity stress, since plant height was not affected, whereas the other morphophysiological parameters became significantly lower than the control only from moderate salinity levels. Salinity tolerance must have probably been favored by the osmotic adjustment provided by increased compatible osmolytes.
\end{abstract}

Keywords: African mahogany, chlorophyll, carbohydrate, proline, salinity stress

\title{
1. Introduction
}

Salinity is one of the most limiting abiotic stress to plant growth and productivity and its origin is often attributed to increasing use of poor quality water for irrigation and soil salinization. Part of the saline-degraded land unsuitable for conventional crop could be used for non-food crops such as alternate plants that can serve to wood as well as landscape 
reintegration (Joseph et al., 2013).

Several studies have reported salinity effects on woody plant development (Niknam and McComb, 2000; Feikema and Baker, 2011; Morais et al., 2012; Rahneshan et al., 2018). Nevertheless, little is known about these effects on mahogany - one of the most valuable tropical woody species worldwide (Nikiema and Pasternak, 2008), whose wood reaches high market value. Khaya senegalensis is the African mahogany species that shows greater rusticity and adaptability to regions with low rainfall (Pinheiro et al., 2011).

Soils with electrical conductivity from $4 \mathrm{dS} \mathrm{m}^{-1}$ (e.g. $\mathrm{NaCl} 40 \mathrm{mM}$ ) are referred as saline soils, where osmotic pressure is close to $-0.2 \mathrm{MPa}$ (Munns and Tester, 2008). In many species, salinity stress causes decreased chlorophyll levels as a typical symptom of oxidative stress, which has been attributed to inhibition of chlorophyll synthesis, together with activation of its degradation by the chlorophyllase enzyme (Taïbi et al., 2016).

Under salinity stress, changes in metabolites content such as soluble sugars and starch, as well as proline content, eventually negatively affect certain plant morphological features e.g., reducing leaf area and leaf number (Acosta-Motos et al., 2017). Carbohydrates can act in osmoprotection, carbon storage, and scavenging of reactive oxygen species and accumulated toxic sodium ion (Gupta and Huang, 2014; Thalmann and Santelia, 2017; Yang and Guo, 2018). Proline, also an osmoprotectant, has antioxidant properties and can act as an enzyme protectant, thus improving plant tolerance to environmental stresses (Verbruggen and Hermans, 2008; Acosta-Motos et al., 2017; Mansour and Ali, 2017; Rahneshan et al., 2018).

This greenhouse reasearch aimed to evaluate the effects of increasing $\mathrm{NaCl}$ concentrations within a nutrient solution on some growth-related morphophysiological and biochemical features in young plants of Khaya senegalensis.

\section{Material and Method}

The study site (14 $53^{\prime} \mathrm{S}, 40^{\circ} 48^{\prime} \mathrm{W} ; 881 \mathrm{~m}$ asl) was a greenhouse located at the Southwest Bahia State University, in Vitória da Conquista, Bahia state, Brazil. During the experimental period, $15 \mathrm{~L}$ pots filled with washed and sieved $(0.005 \mathrm{~mm}$ mesh) sand were kept in the greenhouse with natural sunlight, from Feb (mid-summer) to Jun (late autumn) 2018. The air temperature was maintained between 23 and $26{ }^{\circ} \mathrm{C}$, and relative humidity between 68 and $76 \%$.

Khaya senegalensis 180-day-old seedlings, after grown in little conical tubes, were transplanted into the experimental pots. The completely randomized experiment consisted of six treatments with following $\mathrm{NaCl}$ concentrations: $0 \mathrm{mM}\left(1.0 \mathrm{dS} \mathrm{m}{ }^{-1}\right), 20 \mathrm{mM}\left(3.38 \mathrm{dS} \mathrm{m}^{-1}\right)$, $145 \mathrm{mM}\left(15.14 \mathrm{dS} \mathrm{m}^{-1}\right), 270 \mathrm{mM}\left(29.90 \mathrm{dS} \mathrm{m}^{-1}\right), 395 \mathrm{mM}\left(42.61 \mathrm{dS} \mathrm{m} \mathrm{m}^{-1}\right)$ and $520 \mathrm{mM}$ $\left(53.60 \mathrm{dS} \mathrm{m}^{-1}\right)$. Each treatment was replicated four times. The solutions were prepared by adding $\mathrm{NaCl}$ to Hoagland solution (Hoagland and Arnon, 1950). The solution $\mathrm{pH}$ was adjusted to 6.5 by adding $\mathrm{H}_{2} \mathrm{SO}_{4}$. Salt treatments were imposed in Feb 2018. The plants were irrigated once a day in order to maintain the substrate humidity close to the field capacity and to prevent increasing electrical conductivity (EC) in the root zone. 
At 120 days after the imposition of salt treatments, the plants were removed from the pots, for measurements and analysis of morphophysiological and biochemical features. First, plant height and stem diameter were measured. Then the plants were divided as leaves, stem and roots.

Water potential and relative water content were measured in mature leaves from the middle part of the canopy, at pre-dawn. A pressure chamber (Model 1000, PMS) was used for water potential measurement (Scholander et al., 1965). For relative water content (RWC), fresh (FM), dry (DM) and turgid (TM) leaf discs mass was checked. RWC was obtained by the formula RWC $=[($ FM-DM $) /(T M-D M)]$ (Weatherley, 1950).

Leaf number was verified and a leaf area meter (Li-Cor, model Li-1300, USA) was used for total leaf area measurements. Leaves, stems and roots dry mass were obtained after dried at $70{ }^{\circ} \mathrm{C}$ in an air forced oven for $48 \mathrm{~h}$.

For chlorophyll extraction, acetone $80 \%$ was used, according to Arnon (1949). Extract filtration and preparing followed Amarante et al. (2009) and spectrophotometer analisys was performed according to Wellburn (1994).

Reducing sugars extraction was performed in fully expanded and adult dry leaves using 15 $\mathrm{mL}$ of potassium phosphate buffer $0.1 \mathrm{M}$. Extracts were submitted to three 45 minutes centrifugations at 2,500 $\mathrm{g}$. Anthrone was added to supernatant and reducing sugars content was determined according to Yemm and Willis (1954).

Starch extraction was performed according to McCready et al. (1950). First, boiling ethanol was added to fully expanded and adult dry leaves, followed by maceration, 10 minutes centrifugation at 2,000 $\mathrm{g}$, and supernatant removing, aiming soluble sugars, pigments, phenols and other soluble solutes elimination (Amaral et al., 2007). The precipitate was dried at $65{ }^{\circ} \mathrm{C}$ for $24 \mathrm{~h}$ and resuspended using $52 \%$ perchloric acid, followed by resting for 30 minutes and two 15 minutes centrifugation at 2,000 $\mathrm{g}$. Phenol-sulfuric acid was added to the supernatant, and starch content was determined by spectrophotometer analysis.

Proline content was measured according to Bates et al. (1973). A portion (0.5 g) of tissues was homogenized in $10 \mathrm{ml}$ of $3 \%$ aqueous sulfosalicylic acid, and the homogenate was centrifuged at 2,000 $\mathrm{g}$ for 5 minutes. Aliquots from the extract were added to $2 \mathrm{~mL}$ of acid ninhydrin solution, $2.0 \mathrm{~mL}$ of glacial acetic acid and $1.5 \mathrm{~mL}$ of water. The reaction mixture was incubated for $1 \mathrm{~h}$ at $100{ }^{\circ} \mathrm{C}$ in a water bath. After cooling to ambient temperature, $4 \mathrm{~mL}$ of toluene was added to the reaction mixture, for complete proline extraction, followed by stirring, thereby forming a supernatant. Proline content was measured at $520 \mathrm{~nm}$.

\section{Results}

At the end of the experimental period, the results exhibited diverse toxic effects of increasing $\mathrm{NaCl}$ concentration on growth-related features in young plants of Khaya senegalensis. In our study, no significant effects was found on plant height; however, stem diameter, leaf number, total leaf area and leaf, stem and root dry mass were significantly affected by increased salinity. 


\section{Macrothink}

Stem diameter became significantly lower than the control with increasing electrical conductivity from $29.90 \mathrm{dS} \mathrm{m}^{-1}$; comparing only the plants subjected to salt treatments, there was a decreasing linear effect on stem diameter (Figure 1). Leaf number and total leaf area became significantly lower than the control from $42.61 \mathrm{dS} \mathrm{m}^{-1}$ and $53.60 \mathrm{dS} \mathrm{m}^{-1}$ respectively; comparing only plants subjected to salt treatments, both parameters showed a linear decrease (Figure 2). Salinity played a significant negative effect, marked by a linear decrease on whole plant dry mass, although this effect varied in intensity, depending on which part of the plant (Figure 3). In leaves, for example, dry mass became significantly lower than in control only under $53.60 \mathrm{dS} \mathrm{m}^{-1}$, whereas in roots this difference was observed from $15.14 \mathrm{dS} \mathrm{m}^{-1}$; in stem, dry mass in all salinity levels was lower than in control. The negative effect of salinity stress was more pronounced for roots, whose dry mass declined up to $66 \%$ lower than in control, followed by leaves $(57 \%)$ and stem $(54 \%)$.

$\square$ Control $\square \mathrm{NaCl}$
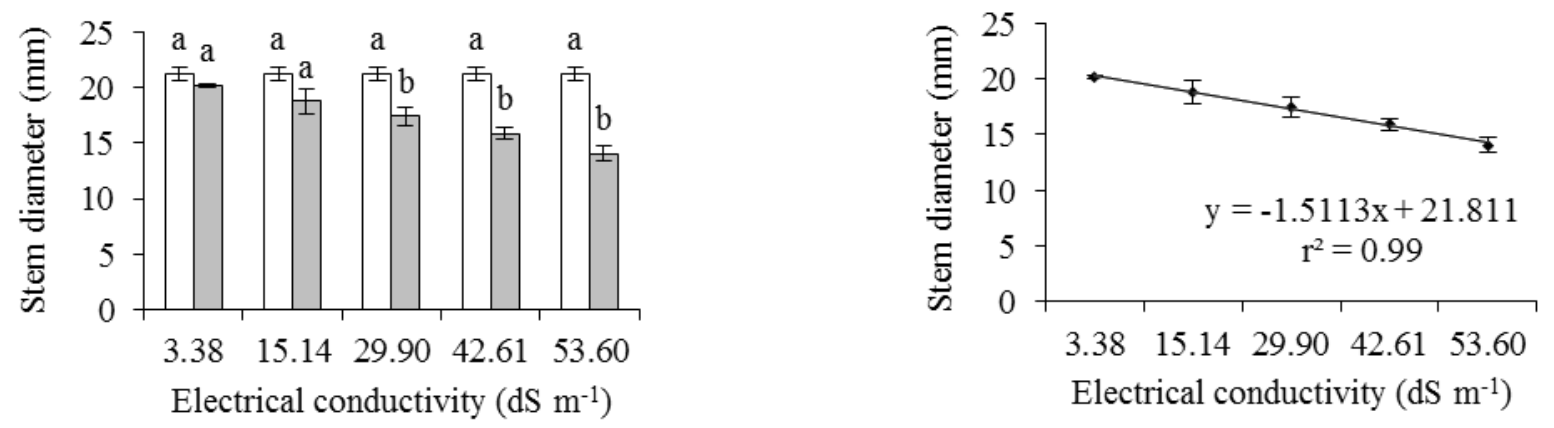

Figure 1. Stem diameter of young plants of Khaya senegalensis grown in pots containing sand + nutrient solution, in the 120th day after imposition of $\mathrm{NaCl}$ treatments and their corresponding electrical conductivities. Vertical bars in columns indicate the standard error of the average of four replications. Within each electrical conductivity, mean values having the same letters indicate that there is no significant difference (Dunnett test, $\mathrm{p}<0.05$ ) between control $\left(\mathrm{NaCl} 0 \mathrm{mM}\right.$, electrical conductivity $\left.1.0 \mathrm{dS} \mathrm{m}{ }^{-1}\right)$ and the $\mathrm{NaCl}$ treatment

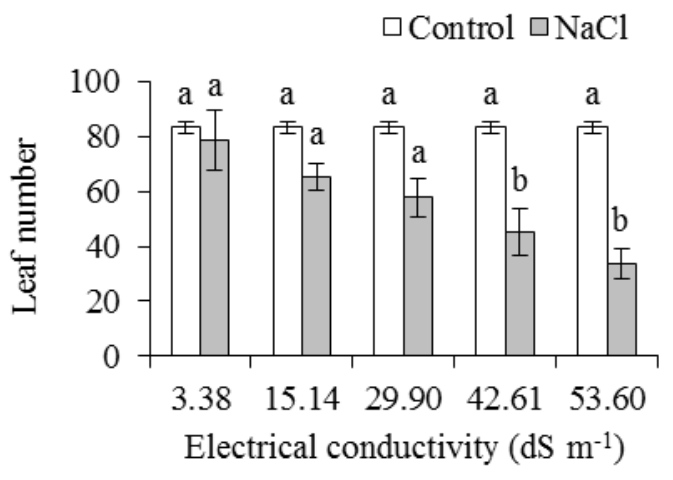



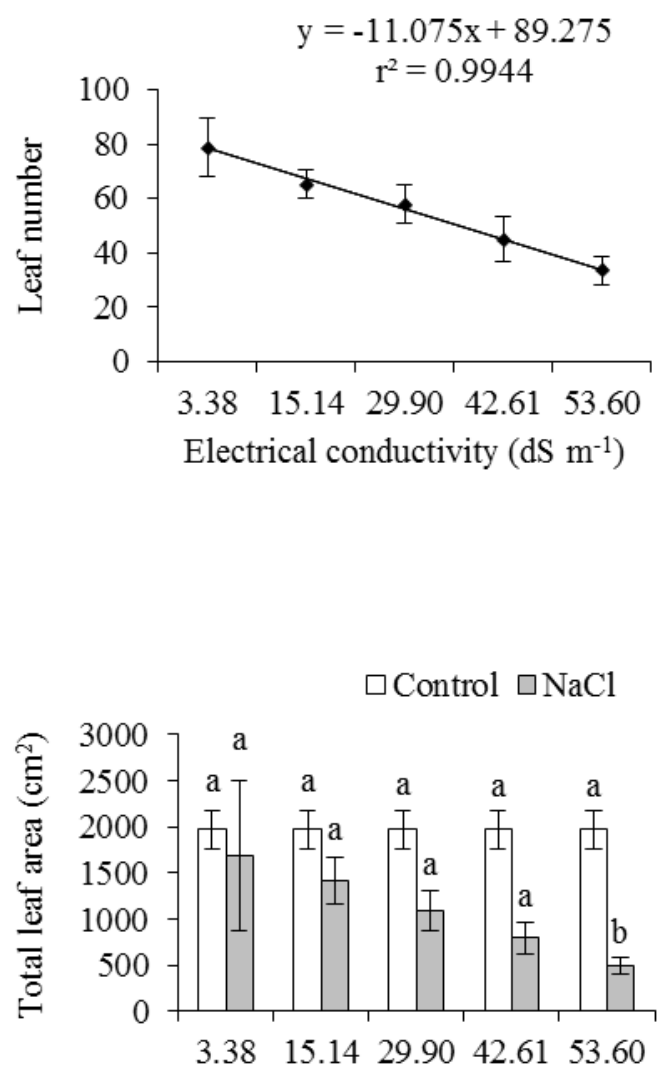

Electrical conductivity $\left(\mathrm{dS} \mathrm{m}^{-1}\right)$

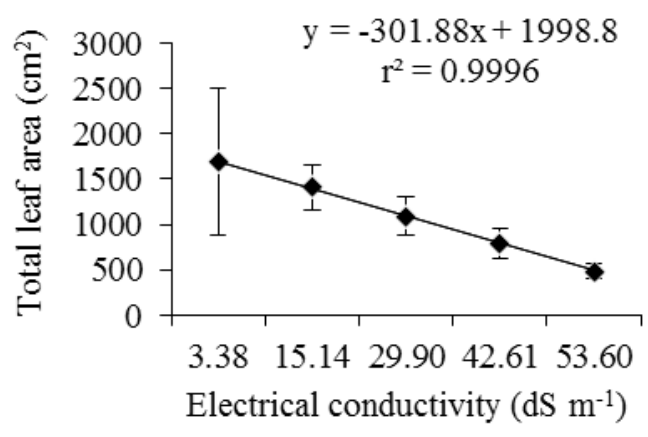

Figure 2. Leaf number and total leaf area of young plants of Khaya senegalensis grown in pots containing sand + nutrient solution, in the 120th day after imposition of $\mathrm{NaCl}$ treatments and their corresponding electrical conductivities. Vertical bars in columns indicate the standard error of the average of four replications. Within each electrical conductivity, mean values having the same letters indicate that there is no significant difference (Dunnett test, $\mathrm{p}<$ $0.05)$ between control $\left(\mathrm{NaCl} 0 \mathrm{mM}\right.$, electrical conductivity $\left.1.0 \mathrm{dS} \mathrm{m}^{-1}\right)$ and the $\mathrm{NaCl}$ treatment 

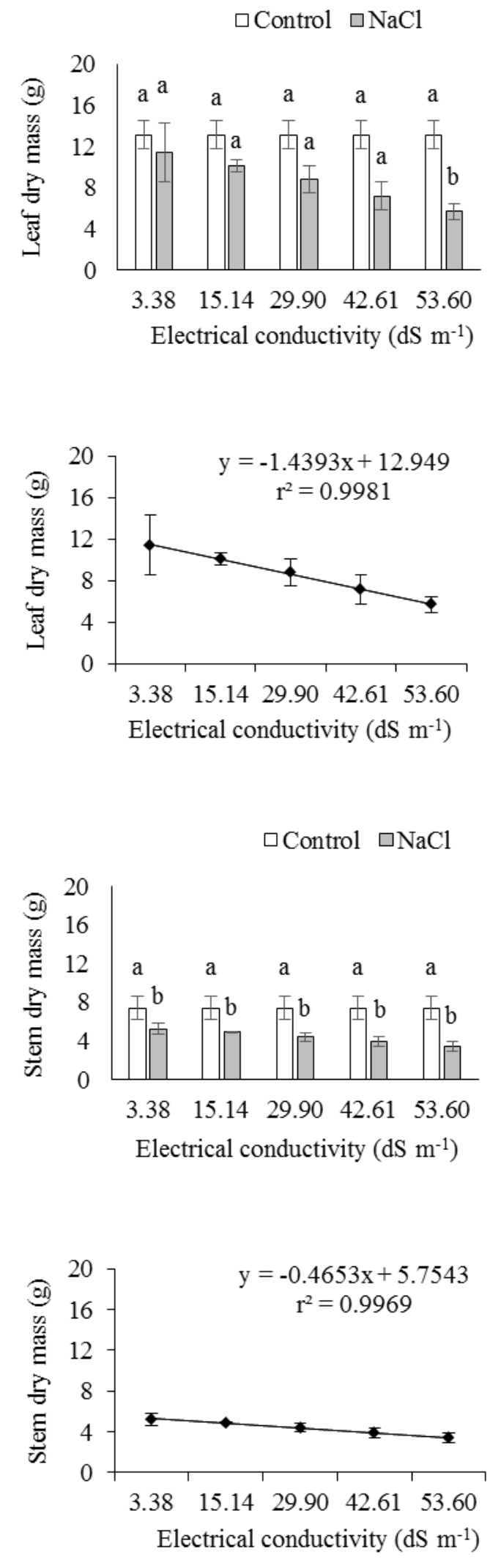

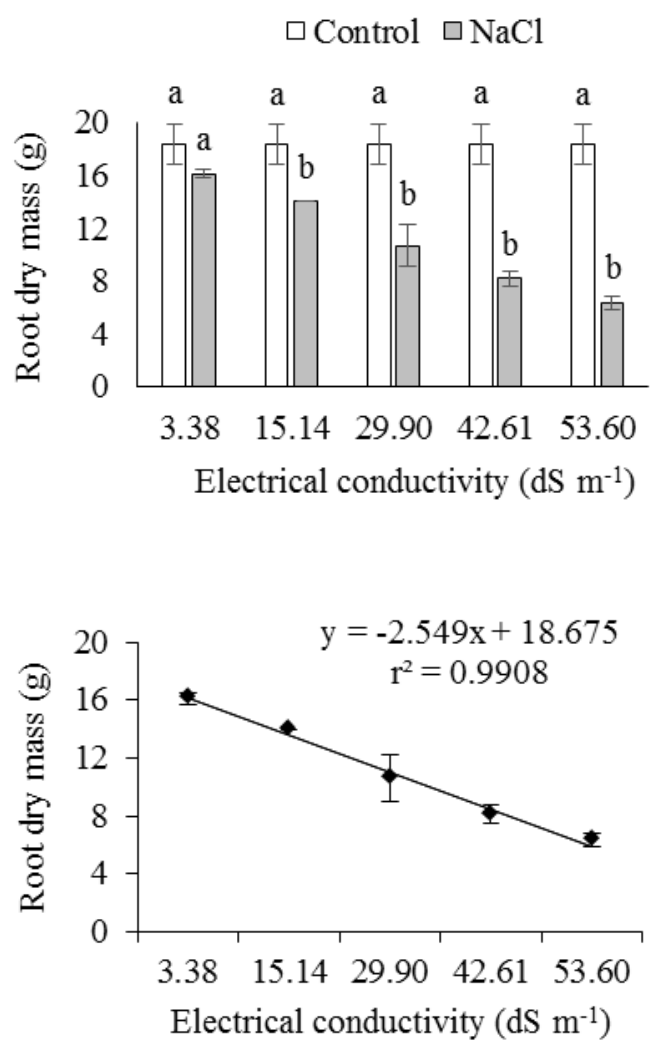

Figure 3. Leaf, stem and root dry mass of young plants of Khaya senegalensis grown in pots containing sand + nutrient solution, in the 120th day after imposition of $\mathrm{NaCl}$ treatments and their corresponding electrical conductivities. Vertical bars in columns indicate the standard error of the average of four replications. Within each electrical conductivity, mean values having the same letters indicate that there is no significant difference (Dunnett test, $\mathrm{p}<0.05$ ) between control $\left(\mathrm{NaCl} 0 \mathrm{mM}\right.$, electrical conductivity $\left.1.0 \mathrm{dS} \mathrm{m}^{-1}\right)$ and the $\mathrm{NaCl}$ treatment

The increase in $\mathrm{NaCl}$ concentration affected plant water status only with respect to leaf water potential (Figure 4), which became significantly lower than in control with increasing electrical conductivity from $15.14 \mathrm{dS} \mathrm{m}^{-1}$. Comparing only the plants subjected to different levels of salinity, the increase in electrical conductivity caused a decreasing quadratic effect on leaf water potential. The relative water content, however, was not affected by the increase in salinity. The decrease in leaf water potential, therefore, must have been mainly due to the increase in osmotically active solute concentrations, suggesting osmotic adjustment. 
Electrical conductivity $\left(\mathrm{dS} \mathrm{m}^{-1}\right)$

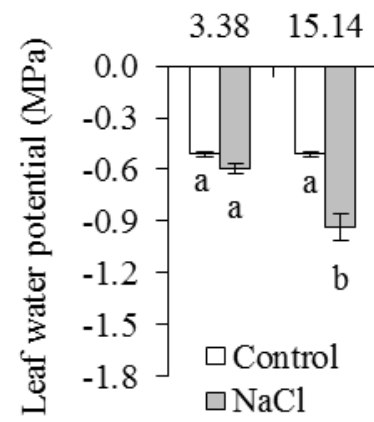

$29.90 \quad 42.61 \quad 53.60$

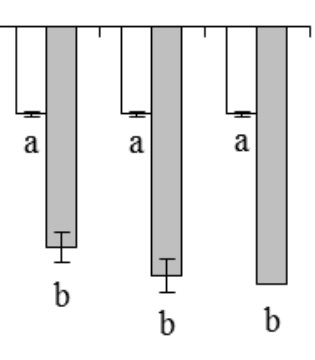

Electrical conductivity ( $\mathrm{dS} \mathrm{m}^{-1}$ )

$\begin{array}{lllll}3.38 & 15.14 & 29.90 & 42.61 & 53.60\end{array}$

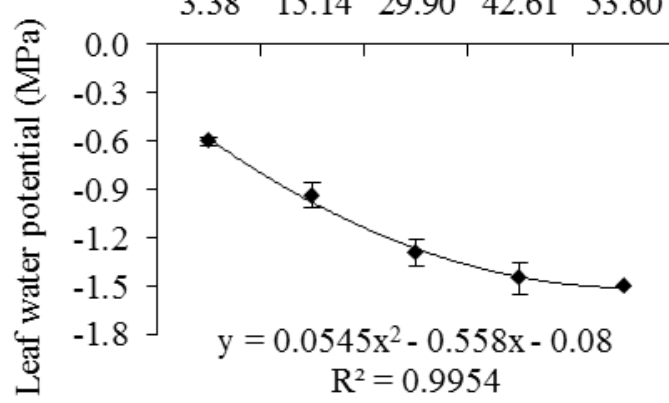

Figure 4. Leaf water potential at pre-dawn, on young plants of Khaya senegalensis grown in pots containing sand + nutrient solution, in the 120th day after imposition of $\mathrm{NaCl}$ treatments and their corresponding electrical conductivities. Vertical bars in columns indicate the standard error of the average of four replications. Within each electrical conductivity, mean values having the same letters indicate that there is no significant difference (Dunnett test, $\mathrm{p}<$ $0.05)$ between control $\left(\mathrm{NaCl} 0 \mathrm{mM}\right.$, electrical conductivity $\left.1.0 \mathrm{dS} \mathrm{m}^{-1}\right)$ and the $\mathrm{NaCl}$ treatment

Chlorophyll content at all electrical conductivity levels was significantly lower than in control. Results showed an inverse relationship between salinity and chlorophyll content: comparing only the plants subjected to salt treatments, there was a decreasing linear effect (Figure 5).

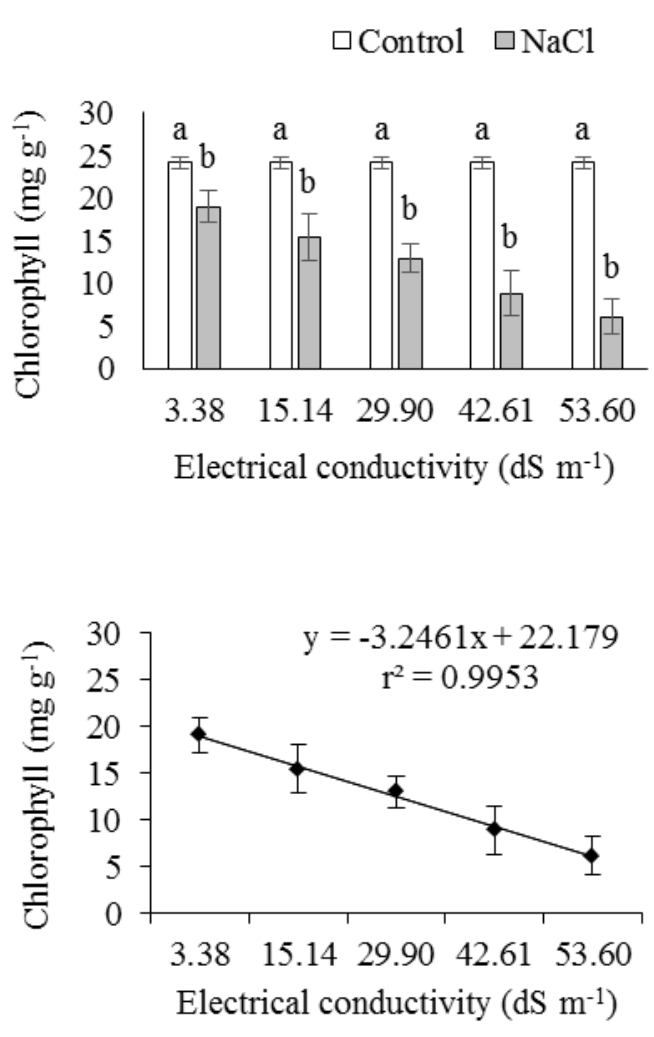




\section{Macrothink}

Figure 5. Chlorophyll content in leaves of young plants of Khaya senegalensis grown in pots containing sand + nutrient solution, in the 120th day after imposition of $\mathrm{NaCl}$ treatments and their corresponding electrical conductivities. Vertical bars in columns indicate the standard error of the average of four replications. Within each electrical conductivity, mean values having the same letters indicate that there is no significant difference (Dunnett test, $\mathrm{p}<0.05$ ) between control $\left(\mathrm{NaCl} 0 \mathrm{mM}\right.$, electrical conductivity $\left.1.0 \mathrm{dS} \mathrm{m}^{-1}\right)$ and the $\mathrm{NaCl}$ treatment

The content of reducing sugars, starch and proline, at all levels of electrical conductivity, were significantly higher than in control. Comparing only plants subjected to salt treatments, there was an increasing linear effect of increasing $\mathrm{NaCl}$ concentration on the contents of these organic compounds (Figures 6 and 7).
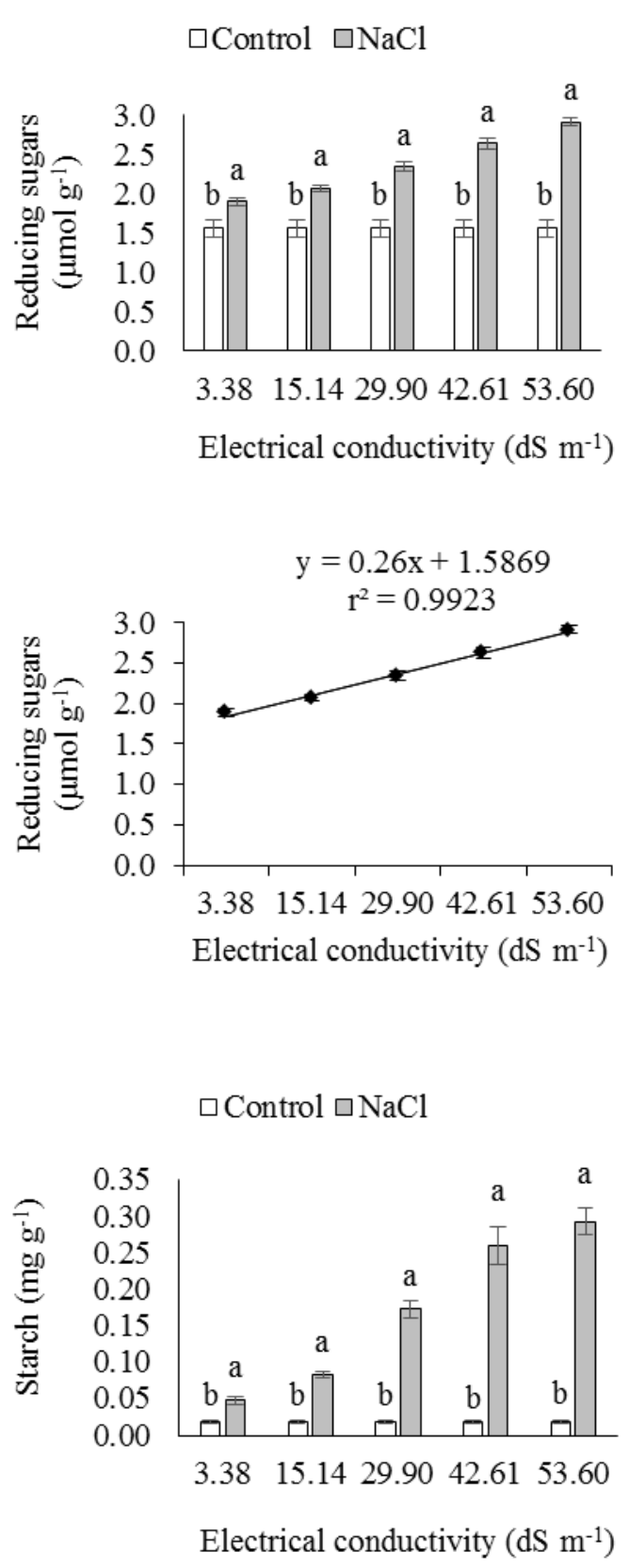


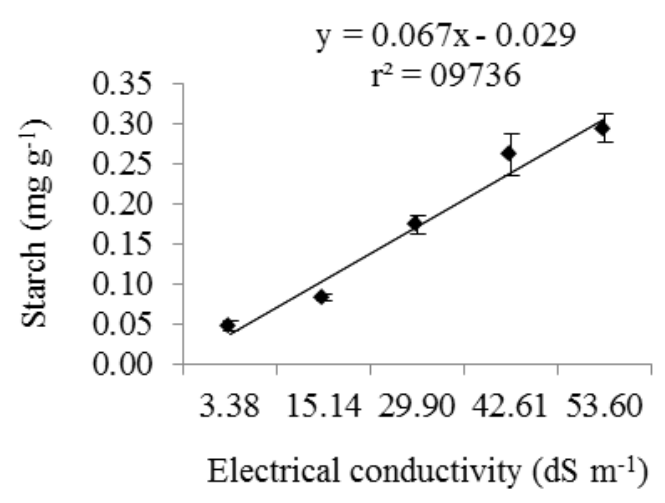

Figure 6. Reducing sugars and starch content in leaves of young plants of Khaya senegalensis grown in pots containing sand + nutrient solution, in the 120th day after imposition of $\mathrm{NaCl}$ treatments and their corresponding electrical conductivities. Vertical bars in columns indicate the standard error of the average of four replications. Within each electrical conductivity, mean values having the same letters indicate that there is no significant difference (Dunnett test, $\mathrm{p}<0.05)$ between control $\left(\mathrm{NaCl} 0 \mathrm{mM}\right.$, electrical conductivity $\left.1.0 \mathrm{dS} \mathrm{m}^{-1}\right)$ and the $\mathrm{NaCl}$ treatment.

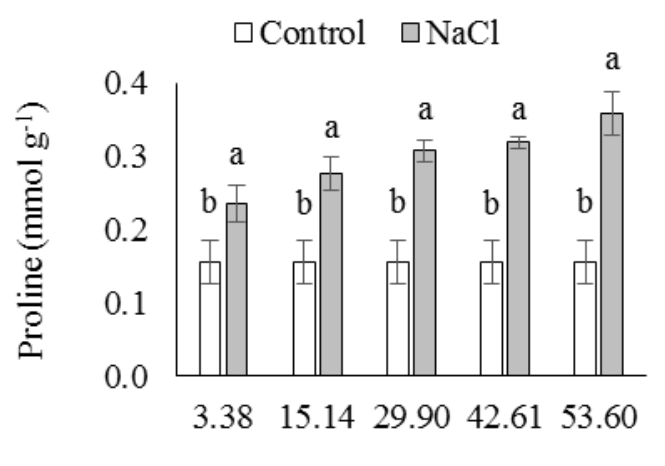

Electrical conductivity $\left(\mathrm{dS} \mathrm{m} \mathrm{m}^{-1}\right)$

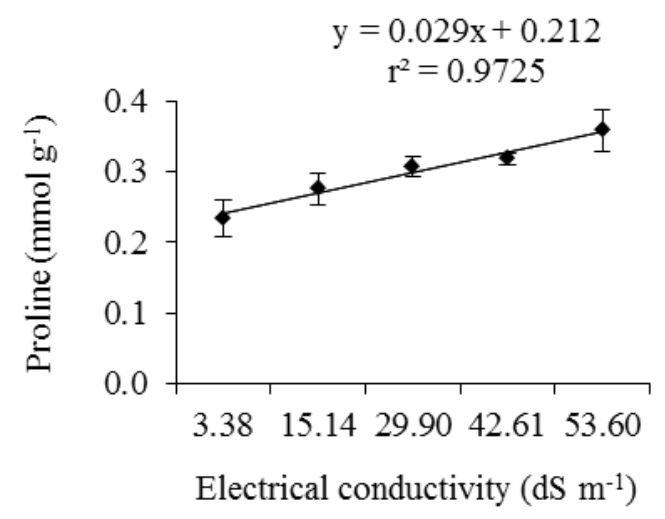


Figure 7. Proline content in leaves of young plants of Khaya senegalensis grown in pots containing sand + nutrient solution, in the 120th day after imposition of $\mathrm{NaCl}$ treatments and their corresponding electrical conductivities. Vertical bars in columns indicate the standard error of the average of four replications. Within each electrical conductivity, mean values having the same letters indicate that there is no significant difference (Dunnett test, $\mathrm{p}<0.05$ ) between control $\left(\mathrm{NaCl} 0 \mathrm{mM}\right.$, electrical conductivity $\left.1.0 \mathrm{dS} \mathrm{m}^{-1}\right)$ and the $\mathrm{NaCl}$ treatment

\section{Discussion}

Salinity stress inhibits plant growth mainly due to osmotic and toxic effects resulting from increased salt concentration in the soil solution. Regarding to osmotic stress, salt accumulation in soil reduces the chemical potential of salt solutions which results in an imbalance of water potential between the apoplast and symplast, causing a reduction in cell turgor pressure. At the conditions of a turgor pressure reduction, there is a significant inhibition of growth (Isayenkov, 2012). In addition, the salt outside the roots plays a toxic affect and negative impact on the establishment of an adequate balance of nutrients required for normal growth in plants (Munns and Tester, 2008).

In the present work, almost all growth-related morphophysiological features, such as stem diameter, leaf number, total leaf area and leaf, stem and root dry mass, were negatively affected by the salinity stress (Figures 1-3). All these changes in plant growth can be considered as responses to the osmotic effect of the salt, and are similar to drought responses. That this reduction is largely due to the osmotic effect of the salt is supported by other experiments using concentrated Hoagland's solution (Termaat and Munns, 1986).

Reduction in leaf number in the canopy area is a typical response to salinity stress reported in different papers. This effect can be considered to prevent salinity stress because it both reduces water loss through perspiration (Ruiz-Sánchez et al., 2000) and contributes to the toxic ions being restricted to the roots, preventing their accumulation in the part (Munns and Tester, 2008). The decrease in total leaf area, in turn, results from changes in cell wall properties, which induce a reduction in leaf turgor and photosynthesis rate (Lima et al., 2018; Rahneshan et al., 2018). According to Munns (1992), salt accumulation in older leaves accelerates their abscission, thus inhibiting the expansion of younger leaves, which become lacking in carbohydrates and hormones for their development. The fact that plant growth is limited by a reduction in the photosynthesis rate and by an excessive uptake of salts affects the production of specific metabolites that directly inhibit growth (Azza Mazher et al., 2007). In addition, stem growth is also usually inhibited by increasing salt concentrations (Acosta-Motos et al., 2017). These salinity stress-related responses have been reported by different authors (Álvarez and Sánchez-Blanco, 2014, 2015; Cirillo et al., 2016).

Decreased dry mass has been observed in all plant tissues subjected to saline stress (Acosta-Motos et al., 2017). Leaf dry mass decrease has been associated to leaf number reduction or leaf abscission (Chartzoulakis et al., 2002). Early events during the osmotic phase of salinity stress promote leaf senescence, resulting from a hormonal imbalance involving the levels of abscisic acid, indole-3-acetic acid and cytokine, prior to the massive accumulation of toxic ions (Ghanem et al., 2008). However, it is the efficient conversion of 
aminocyclopropane carboxylic acid to ethylene that notably initiates oxidative damage, decreases in chlorophyll fluorescence and massive $\mathrm{Na}^{+}$accumulation, leading to leaf abscission (Albacete et al., 2008).

The results indicated that the negative effect of salinity stress was more pronounced on roots, whose dry mass declined up to $66 \%$ lower than in control, followed by leaves $(57 \%)$ and stem (54\%). This is a surprising result, as shoot growth is usually considered to be more sensitive than root growth to salinity stress, and this effect is often attributed to a reduction in leaf number and total leaf area in compared with root growth, aiming to decrease the water use by the plant, thus allowing to conserve soil moisture and to prevent salt concentration in the soil (Munns and Tester, 2008). In a study on salinity tolerance in six native woody species from the Brazilian semi-arid region, less dry mass decrease in some species was correlated to two factors - higher stomatal control and water use efficiency (Bessa et al., 2017). In the present study, we considered that these factors may have been the reason why the dry mass decrease in leaves was less pronounced than in roots.

Another interesting growth parameter is plant architecture, based on the relationship between foliage size and plant height. For ornamental plants, for example, high values of this relationship are indicators of plant compactness, which is a desirable aesthetic and commercial feature, and is much appreciated by nurseries and consumers (Sánchez-Blanco et al., 2014; Álvarez and Sánchez-Blanco, 2015). In the present study, however, plant height was not affected by increased salinity, resulting in a decrease in the relationship between foliage size and plant height. In general, it can be inferred that the stem meristem, under increasing salt concentrations, can induce osmotic adjustment, thus avoiding reduction in height growth (Abdul Qados, 2011).

There is no available information in the literature about the effect of salinity stress on height-to-stem diameter ratio, and consequently on the balance between height and diameter growth, in broad-leaved species. However, in a study conducted by Espinoza et al. (2013) on a coniferous species (Pinus radiata D. Don) these authors observed that water stress increased height-to-stem diameter ratio comparatively to well-watered treatment. In our study, salinity stress effect resulted also in an increase in a height-to-stem diameter ratio compared to control. This suggests that, under salinity stress, stem dry mass partitioning is marked by the allocation of more resources for growth in height than in diameter. The reason for this answer is unclear, but it may reflect strong plasticity of this species.

The decline in leaf water potential with increasing $\mathrm{NaCl}$ concentration, as observed in the present study (Figure 4), is a known response of plants to salinity stress (Tattini and Traversi, 2009; Gupta and Huang, 2014). Decreased water potential under salinity stress may result from loss of some water in plant tissues, which implies reduced cell volume and consequent inhibition in cell division, among other deleterious physiological effects (Hsiao and $\mathrm{Xu}$, 2000).

Under saline conditions, however, plants often make osmotic adjustment, in which they reduce their osmotic potential by increasing the concentration of neutral salts and / or solutes, thereby minimizing changes in pressure potential. The concentration of these compatible 
solutes within the cell is maintained either by irreversible synthesis of the compounds or by a combination of synthesis and degradation (Gupta and Huang, 2014). Decreasing in water potential by soluble osmolytes accumulation can mitigate water loss, thus maintaining turgor and cell expansion, providing continuous growth under salinity stress (Apse and Blumwald, 2002).

In the present study, the chlorophyll content was significantly reduced by salinity treatments (Figure 5). The decrease in chlorophyll levels in salinity-stressed plants has been considered as a biochemical marker of salinity tolerance in plants as it is a typical symptom of oxidative stress, with toxic $\mathrm{Na}^{+}$affecting more markedly chlorophyll biosynthesis than chlorophyll breakdown by the enzyme chlorophyllase (Ashraf and Harris, 2013). It has been accepted that the photosynthesis rate may drop due to a decrease in chlorophyll content. Nevertheless, our results showed that photosynthesis apparently was not affected by the increase in electrical

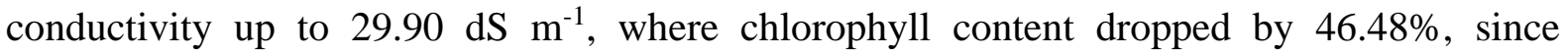
growth-related leaf morphophysiological features such as leaf number, total leaf area and leaf dry mass were not different from the control, suggesting tolerance to salinity stress.

The contents of reducing sugars, starch and proline increased with increasing $\mathrm{NaCl}$ concentration (Figures 6 and 7). Under salinity stress, plants accumulate compatible solutes such as soluble sugars and proline which are known for their osmoprotection activity (Gupta and Hang, 2014). The accumulation of metabolites that act as compatible solutes is one of the common responses of plants to changes in the external osmotic potential (Munns and Tester, 2008). In the presente study, we believed that the noticeable increase in leaf reducing sugar content, with the increasing electrical conductivity, can be related to allocation of assimilates which contribute to osmotic adjustment (Hajiboland et al., 2014). This understanding is corroborated by the decrease in leaf water potential associated with the unchanged relative water content. It has been observed that salinity stress increases the level of reducing sugars within the cell in a number of plants belonging to different species (Kerepesi and Galiba, 2000).

In the present study, the increase in starch content was a result opposite to that observed in many species when they are subjected to abiotic stresses. In the majority of the studies, leaf starch content was reported to decrease in response to abiotic stress, irrespectively of the analyzed species. Under environmental stress, plants often resort to stored starch as a source of energy and carbon, making it a metabolic alternative to compensate for photosynthetic limitations (Thalmann and Santelia, 2017). Thus, sugars resulting from starch degradation can act as both osmoprotectors and compatible solutes to mitigate negative effects of stress (Krasensky and Jonak, 2012). However, in some studies, an increase in starch content has been found in plants under salinity stress (Kanai et al., 2007; Skirycz et al., 2010; Yin et al., 2010; Wang et al., 2013; Monroe et al., 2014; Zanella et al., 2016). The reasons for the variation in starch content as a response to salinity stress are not yet clear, because it may depend on both the species or experimental conditions. In halophytes, for example, increased starch content has been identified as a strategic mechanism for eliminating sodium (Kanai et al., 2007). These alternative metabolic pathways for starch utilization, as even discrepant responses to salinity stress, highlight starch plasticity and demonstrate that it cannot merely 
be considered a storage compound (Thalmann and Santelia, 2017).

Proline accumulation, as observed in the present study, is one of the most important changes in plant metabolism in response to salinity stress. This effect is consistent with previous reports in which proline accumulation was related to plant tolerance to increasing salt concentrations (Ahmad et al., 2016; Nahar et al., 2016; Pardo-Domenech et al., 2016). Proline usually increases more markedly than other amino acids in plants under salinity stress (Choudhury et al., 2007; Slama et al., 2015). Besides being a compatible osmolyte, proline also plays an enzyme-protecting role, free radical scavenger and cellular redox balancer (Verbruggen and Hermans, 2008; Mansour and Ali, 2017).

\section{Conclusion}

After 120 days under increasing $\mathrm{NaCl}$ concentration in nutrient solution, the results of this study showed that the salinity stress differently affects morphopysiological and biochemical features in the early stages of Khaya senegalensis development. Among the growth-related parameters, we highlight the fact that plant height, in particular, was not affected under all salt concentrations. Moreover, most other morphophysiological parameters, such as stem diameter, leaf number, total leaf area and leaf, stem and root dry mass, became significantly lower than the control only from moderate salinity levels. These results allow us to conclude that this is a species tolerant to salinity stress, at least in the early stages of its development. Our study indicates that osmotic adjustment was one of the salinity stress tolerance strategies, as the increase in electrical conductivity induced a decrease in leaf water potential, whereas the relative water content was not affected. The decrease in chlorophyll content appers to have been a plant response to the toxic effect of leaf salt accumulation. The increased levels of reducing sugars and proline was a typical osmoregulatory plant response to increasing salinity, whereas the increase in starch content may have helped to reduce the toxic sodium ions accumulation.

\section{Acknowledgements}

The authors wish to express their sincere thanks to the following Brazilian research support institutions: Universidade Estadual do Sudoeste da Bahia (UESB), Coordenação de Aperfeiçoamento de Pessoal de Nível Superior (CAPES), Conselho Nacional de Desenvolvimento Científico e Tecnológico $(\mathrm{CNPq})$ and Fundação de Amparo à Pesquisa do Estado da Bahia (FAPESB).

\section{References}

Abdul Qados, M. A. S. (2011). Effect of salt stress on plant growth and metabolism of bean plant Vicia faba (L.). Journal of the Saudi Society of Agricultural Sciences, 10, 7-15. https://doi.org/10.1016/j.jssas.2010.06.002

Acosta-Motos, J., Ortuño, M., Bernal-Vicente, A., Diaz-Vivancos, P., Sanchez-Blanco, M., \& Hernandez, J. (2017). Plant responses to salt stress: adaptive mechanisms. Agronomy, 7, 18. https://doi.org/10.3390/agronomy7010018

Ahmad, P., Abdel Latef, A. A., Hashem, A., Abdel Allah, E. F., Gucel, S., \& Tran, L. P. (2016). 
Nitric oxide mitigates salt stress by regulating levels of osmolytes and antioxidant enzymes in chickpea. Frontiers in Plant Science, 7, 347. https://doi.org/10.3389/fpls.2016.00347

Albacete, A., Ghanem, M. E., Martínez-Andújar, C., Acosta, M., Sánchez-Bravo, J., Martínez, V., ... Pérez-Alfocea, F. (2008). Hormonal changes in relation to biomass partitioning and shoot growth impairment in salinized tomato (Solanum lycopersicum L.) plants. Journal of Experimental Botany, 59, 4119-4131. https://doi.org/10.1093/jxb/ern251

Álvarez, S., \& Sánchez-Blanco, M. J. (2014). Long-term effect of salinity on plant quality, water relations, photosynthetic parameters and ion distribution in Callistemon citrinus. Plant Biology, 16, 757-764. https://doi.org/10.1111/plb.12106

Álvarez, S., \& Sánchez-Blanco, M. J. (2015). Comparison of individual and combined effects of salinity and deficit irrigation on physiological, nutritional and ornamental aspects of tolerance in Callistemon laevis plants. Journal of Plant Physiology, 185, 65-74. https://doi.org/10.1016/j.jplph.2015.07.009

Amaral, L. I. V., Gaspar, M., Costa, P. M. F., Aidar, M. P. M., \& Buckeridg, M. S. (2007). New fast and sensitive enzymatic method of starch extraction and dosing in plant materials. Hoehnea, 34, 425-431. https://doi.org/10.1590/S2236-89062007000400001

Amarante, C. V. T., Zanardi, O. Z., Aquidauana, M., Steffens, C. A., Erhart, J., \& Almeida, J. A. (2009). Quantification of area and chlorophyll content in leaves of cabernet sauvignon young grapevine by non-destructive methods. Revista Brasileira de Fruticultura, 31, 680-686. https://doi.org/10.1590/S0100-29452009000300009

Apse, M. P., \& Blumwald, E. (2002). Engineering salt tolerance in plants. Current Opinion in Biotechnology, 13, 146-150. https://doi.org/10.1016/s0958-1669(02)00298-7

Arnon, D. I. (1949). Cooper enzymes in isolated chloroplasts: Polyphenoloxidase in Beta vulgaris. Plant Physiology, 24, 1-15. https://doi.org/10.1104/pp.24.1.1

Ashraf, M., \& Harris, P. J. C. (2013). Photosynthesis under stressful environments: An overview. Photosynthetica, 51, 163-190. https://doi.org/10.1007/s11099-013-0021-6

Azza Mazher, A. M., Fatma El-Quesni, E. M., \& Farahat, M. M. (2007). Responses of ornamental plants and woody trees to salinity. World Journal of Agricultural Sciences, 3, 386-395.

Bates, L. S., Waldren, R. P., \& Teare, I. D. (1973). Rapid determination of free proline for water stress studies. Plant and Soil, 39, 205-207. https://doi.org/10.1007/BF00018060

Bessa, M. C., Lacerda, C. F., Amorim, A. V., Bezerra, A. M. E., \& Lima, A. D. (2017). Mechanisms of salt tolerance in seedlings of six woody native species of the Brazilian semi-arid. Revista Ciência Agronômica, 48, 157-165. http://doi.org/10.5935/1806-6690.20170018

Chartzoulakis, K., Loupassaki, M., Bertaki, M., \& Androulakis, I. (2002). Effects of NaCl salinity on growth, ion content and $\mathrm{CO}_{2}$ assimilation rate of six olive cultivars. Scientia 
Horticulturae, 96, 235-247. https://doi.org/10.1016/S0304-4238(02)00067-5

Choudhury, A. R., Roy, C., \& Sengupta, D. N. (2007). Transgenic tobacco plants overexpressing the heterologous lea gene Rab16A from rice during high salt and water deficit display enhanced tolerance to salinity stress. Plant Cell Reports, 26, 1839-1859. https://doi.org/10.1007/s00299-007-0371-2

Cirillo, C., Rouphael, Y., Caputo, R., Raimondi, G., Sifola, M. I., \& De Pascale, S. (2016). Efects of high salinity and the exogenous of an osmolyte on growth, phosynthesis and mineral composition in two ornamental shrubs. Journal of Horticultural Science and Biotechnology, 91, 14-22. https://doi.org/10.1080/14620316.2015.1110988

Espinoza, S. E., Magni, C. R., Martínez, V. A., \& Ivković. (2013). The effect of water availability on plastic responses and biomass allocation in early growth traits of Pinus radiata D. Don. Forest Systems, 22, 3-14. https://doi.org/10.5424/fs/2013221-02084

Feikema, P. M., \& Baker, T. G. (2011). Effect of soil salinity on growth of irrigated plantation Eucalyptus in south-eastern Australia. Agricultural Water Management, 98, 1180-1188. https://doi.org/10.1016/j.agwat.2011.03.005

Ghanem, M. E., Albacete, A., Martínez-Andújar, C., Acosta, M., Romero-Aranda, R., Dodd, I. C., ... Pérez-Alfocea, F. (2008). Hormonal changes during salinity-induced leaf senescence in tomato (Solanum lycopersicum L.). Journal of Experimental Botany, 59, 3039-3050. https://doi.org/10.1093/jxb/ern153

Gupta, B., \& Huang, B. (2014). Mechanism of salinity tolerance in plants: physiological, biochemical, and molecular characterization. International Journal of Genomics, 2014, 1-18. https://doi.org/10.1155/2014/701596

Hajiboland, R., Norouzi, F., \& Poschenrieder, C. (2014). Growth, physiological, biochemical and ionic responses of pistachio seedlings to mild and high salinity. Trees, 28, 1065-1078. https://doi.org/10.1007/s00468-014-1018-x

Hoagland, D. R., \& Arnon, D. I. (1950). The waterculture method for growing plants without soil. Berkeley, California, USA, College of Agriculture, University of California. p. 34.

Hsiao, T. C., \& Xu, L. K. (2000). Sensitivity of growth of roots versus leaves to water stress: biophysical analysis and relation to water transport. Journal of Experimental Botany, 51, 1595-616. https://doi.org/10.1093/jexbot/51.350.1595

Isayenkov, S. V. (2012). Physiological and molecular aspects of salt stress in plants. Cytology and Genetics, 46, 302-318. https://doi.org/10.3103/S0095452712050040

Joseph, S., Murphy, D. J., Miller, J. T., \& Bhave, M. (2013). Application of molecular markers for identification of potential salt tolerant plant species for use in agroforestry and saline land reclamation. APCBEE Procedia, 5, 514-519. https://doi.org/10.1016/j.apcbee.2013.05.087

Kanai, M., Higuchi, K., Hagihara, T., Konishi, T., Ishii, T., Fujita, N., ... Tadano, T. 
(2007). Common reed produces starch granules at the shoot base in response to salt stress. New Phytologist, 176, 572-580. https://doi.org/10.1111/j.1469-8137.2007.02188.x

Kerepesi, I., \& Galiba, G. (2000). Osmotic and salt stress-induced alteration in soluble carbohydrate content in wheat seedlings. Crop Science, 40, 482-487. https://doi.org/10.2135/cropsci2000.402482x

Krasensky, J., \& Jonak, C. (2012). Drought, salt, and temperature stress-induced metabolic rearrangements and regulatory networks. Journal of Experimental Botany, 63, 1593-1608. https://doi.org/10.1111/nph.14491

Lima, A. D., Bezerra, F. M. S., Neves, A. L. R., Sousa, C. H. C., Lacerda, C. F., \& Bezerra, A. M. E. (2018). Response of four woody species to salinity and water deficit in initial growth phase. Revista Brasileira de Engenharia Agrícola e Ambiental, 22, 753-757. https://doi.org/10.1590/1807-1929/agriambi.v22n11p753-757

Mansour, M. M. F., \& Ali, E. F. (2017). Evaluation of proline functions in saline conditions. Phytochemistry, 140, 52-68. https://doi.org/10.1016/j.phytochem.2017.04.016

McCready, R. M., Guggolz, J., Silviera, V., \& Owens, H. S. (1950). Determination of starch and amylose in vegetables. Analytical Chemistry, 22, 1156-1158. https://doi.org/10.1021/ac60045a016

Monroe, J. D., Storm, A. R., Badley, E. M., Lehman, M. D., Platt, S. M., Saunders, L. K., Schmitz, J. M., \& Torres, C. E. (2014). $\beta$-Amylase1 and $\beta$-Amylase3 are plastidic starch hydrolases in Arabidopsis that seem to be adapted for different thermal, ph, and stress conditions. Plant Physiology, 166, 1748-1763. https://doi.org/10.1104/pp.114.246421

Morais, M. C., Panuccio, M. R., Muscolo, A., \& Freitas, H. (2012). Salt tolerance traits increase the invasive success of Acacia longifolia in Portuguese coastal dunes. Plant Physiology and Biochemistry, 55, 60-65. https://doi.org/10.1016/j.plaphy.2012.03.013

Munns, R. (1992). A leaf elongation assay detects an unknown growth inhibitor in xylem sap from wheat and barley. Australian Journal of Plant Physiology, 19, 127-135. https://doi.org/10.1071/PP9920127

Munns, R., \& Tester, M. (2008). Mechanisms of salinity tolerance. Annual Review of Plant Biology, 59, 651-681. https://doi.org/10.1146/annurev.arplant.59.032607.0

Nahar, K., Hasanuzzaman, M., \& Fujita, M. (2016). Roles of osmolytes in plant adaptation to drought and salinity. In: N. Iqbal, R. Nazar, \& N. Khan (Eds.), Osmolytes and plants acclimation to changing environment: emerging omics technologies (pp. 37-68). India, Springer. https://doi.org/10.1007/978-81-322-2616-1_4

Nikiema, A., \& Pasternak, D. (2008). Khaya senegalensis (Desr.) A. Juss. In: D. Louppe, A. A. Oteng-Amoako, \& M. Brink (Eds.), Plant resources of tropical Africa (pp. 339-344). Wageningen, Netherlands, PROTA.

Niknam, S., \& McComb, J. (2000). Salt tolerance screening of selected Australian woody 
species - a review. Forest Ecology and Management, 139, 1-19. https://doi.org/10.1016/s0378-1127(99)00334-5

Pardo-Domenech, L. L., Tifrea, A., Grigore, M. N., Boscaiu, M., \& Vicente, O. (2016). Proline and glycine betaine accumulation in two succulent halophytes under natural and $\begin{array}{lllll}\text { experimental conditions. Plant } & \text { Biosystems, } & \text { 150, }\end{array}$ https://doi.org/10.1080/11263504.2014.990943

Pinheiro, A. L., Couto, L., Pinheiro, D. T., \& Brunetta, J. M. F. C. (2011). Ecology, forestry and technology of utilization of African mahogany (Khaya spp.). Viçosa, MG, Brasil, Sociedade Brasileira de Agrossilvicultura. p. 102.

Rahneshan, Z., Nasibi, F., \& Moghadam, A. A. (2018). Effects of salinity stress on some growth, physiological, biochemical parameters and nutrients in two pistachio (Pistacia vera L.) rootstocks. Journal of Plant Interactions, 13, 73-82. https://doi.org/10.1080/17429145.2018.1424355

Ruiz-Sánchez, M. C., Domingo, R., Torrecillas, A., \& Pérez-Pastor, A. (2000). Water stress preconditioning to improve drought resistance in young apricot plants. Plant Science, 156, 245-251. https://doi.org/10.1016/S0168-9452(00)00262-4

Sánchez-Blanco, M. J., Álvarez, S., Ortuño, M. F., \& Ruiz-Sánchez, M. C. (2014). Root system response to drought and salinity: root distribution and water transport. In: A. Morte, \& A. Varma (Eds.), Root engineering (pp. 325-352). Berlin, Germany, Springer. https://doi.org/10.1007/978-3-642-54276-3_15

Scholander, P. F., Bradstreet, E. D., Hemmingsen, E. A., \& Hammel, H. T. (1965). Sap pressure in vascular plants. Science, 148, 339-346. https://doi.org/10.1126/science.148.3668.339

Skirycz, A., De Bodt, S., Obata, T., De Clercq, I., Claeys, H., De Rycke, R., Andriankaja, M., Van Aken, O., Breusegem, F. V., Fernie, A. R., \& Inzé, D. (2010). Developmental stage specificity and the role of mitochondrial metabolism in the response of Arabidopsis leaves to prolonged mild osmotic stress. Plant Physiology, 152, 226-244. https://doi.org/10.1104/pp.109.148965

Slama, I., Abdelly, C., Bouchereau, A., Flowers, T., \& Savoure, A. (2015). Diversity, distribution and roles of osmoprotective compounds accumulated in halophytes under abiotic stress. Annals of Botany, 115, 433-447. https://doi.org/10.1093/aob/mcu239

Taïbi, K., Taïbi, F., Ait Abderrahim, L., Ennajah, A., Belkhodja, M., \& Mulet, J. M. (2016). Effect of salt stress on growth, chlorophyll content, lipid peroxidation and antioxidant defence systems in Phaseolus vulgaris L. South African Journal of Botany, 105, 306-312. https://doi.org/10.1016/j.sajb.2016.03.011

Tattini, M., \& Traversi, M. (2009). On the mechanism of salt tolerance in olive (Olea europaea L.) under low- or high- $\mathrm{Ca}^{2+}$ supply. Environmental and Experimental Botany, 65, 72-81. https://doi.org/10.1016/j.envexpbot.2008.01.005 


\section{Al Macrothink}

Journal of Agricultural Studies

ISSN 2166-0379

2020, Vol. 8, No. 3

Termaat, A., \& Munns, R. (1986). Use of concentrated macronutrient solutions to separate osmotic from NaCl-specific effects on plant growth. Australian Journal of Plant Physiology, 13, 509-22. https://doi.org/10.1071/PP9860509

Thalmann, M., \& Santelia, D. (2017). Starch as a determinant of plant fitness under abiotic stress. New Phytologist, 214, 943-951. https://doi.org/10.1111/nph.14491

Verbruggen, N., \& Hermans, C. (2008). Proline accumulation in plants: a review. Amino Acids, 35, 753-759. https://doi.org/10.1007/s00726-008-0061-6

Wang, X., Chang, L., Wang, B., Wang, D., Li, P., Wang, L., ... Guo, A. (2013). Comparative proteomics of Thellungiella halophila leaves from plants subjected to salinity reveals the importance of chloroplastic starch and soluble sugars in halophyte salt tolerance. Molecular \& Cellular Proteomics, 12, 2174-2195. https://doi.org/10.1074/mcp.m112.022475

Weatherley, P. E. (1950). Studies in the water relations of the cotton plant. I - The field measurements of water deficits in leaves. New Phytologist, 49, 81-97. https://doi.org/10.1111/j.1469-8137.1950.tb05146.x

Wellburn, A. R. (1994). The spectral determination of chlorophylls a and b, as well as total carotenoids, using various solvents with spectrophotometers of different resolution. Journal of Plant Physiology, 144, 307-313. https://doi.org/10.1016/S0176-1617(11)81192-2

Yang, Y., \& Guo, Y. (2017). Elucidating the molecular mechanisms mediating plant salt-stress responses. New Phytologist, 217, 523-539. https://doi.org/10.1111/nph.14920

Yemm, E. W., \& Willis, A. J. (1954). The estimation of carbohydrates in plant extracts by anthrone. Biochemical Journal, 57, 508-515. https://doi.org/10.1042/bj0570508

Yin, Y. G., Kobayashi, Y., Sanuki, A., Kondo, S., Fukuda, N., Ezura, H., Sugaya, S., \& Matsukura, C. (2010). Salinity induces carbohydrate accumulation and sugar-regulated starch biosynthetic genes in tomato (Solanum lycopersicum L. cv. "Micro-Tom") fruits in an ABAand osmotic stress-independent manner. Journal of Experimental Botany, 61, 563-574. https://doi.org/10.1093/jxb/erp333

Zanella, M., Borghi, G. L., Pirone, C., Thalmann, M., Pazmino, D., Costa, A., ... Sparla, F. (2016). $\beta$-amylase1 (BAM1) degrades transitory starch to sustain proline biosynthesis during drought stress. Journal of Experimental Botany, 67, 1819-1826. https://doi.org/10.1093/jxb/erv572

\section{Copyright Disclaimer}

Copyright for this article is retained by the author(s), with first publication rights granted to the journal.

This is an open-access article distributed under the terms and conditions of the Creative Commons Attribution license (http://creativecommons.org/licenses/by/4.0/). 